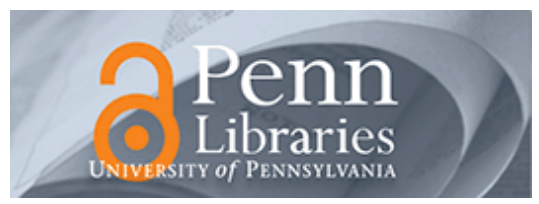

University of Pennsylvania ScholarlyCommons

September 2004

\title{
A biogeochemical analysis of the Pocono till barrens and adjacent hardwood forest underlain by Wisconsinan and Illinoian till in northeastern Pennsylvania
}

Anne W. Wibiralske

Hobart and William Smith Colleges

Roger Earl Latham

Continental Conservation

Arthur H. Johnson

University of Pennsylvania, ahj@sas.upenn.edu

Follow this and additional works at: https://repository.upenn.edu/ees_papers

\section{Recommended Citation}

Wibiralske, A. W., Latham, R., \& Johnson, A. H. (2004). A biogeochemical analysis of the Pocono till barrens and adjacent hardwood forest underlain by Wisconsinan and Illinoian till in northeastern Pennsylvania. Retrieved from https://repository.upenn.edu/ees_papers/13

Copyright NRC Research Press. Published in Canadian Journal of Forest Research, Volume 34, Number 9 , September 2004, pages 1819-1832.

Publisher URL: http://pubs.nrc-cnrc.gc.ca

This paper is posted at ScholarlyCommons. https://repository.upenn.edu/ees_papers/13

For more information, please contact repository@pobox.upenn.edu. 


\title{
A biogeochemical analysis of the Pocono till barrens and adjacent hardwood forest underlain by Wisconsinan and Illinoian till in northeastern Pennsylvania
}

\begin{abstract}
We assessed soil and vegetation nutrient capital in the landscape mosaic of till barrens and hardwood forests on the Pocono Plateau in northeastern Pennsylvania. These shrublands, which contain an unusual abundance of rare species, occur primarily on Illinoian-aged glacial till, though some patches grow on Wisconsinan till. We hypothesized that barrens soil and vegetation contain smaller quantities of nutrients than forest soil and vegetation, and under the same vegetation, Illinoian till soils have a smaller nutrient content than Wisconsinan till soils. We measured $\mathrm{pH}$, total $\mathrm{C}$ and $\mathrm{N}$, and exchangeable $\mathrm{Ca}, \mathrm{Mg}, \mathrm{K}$, and $\mathrm{Al}$ content of the soils and determined $\mathrm{C}, \mathrm{N}, \mathrm{Ca}, \mathrm{Mg}, \mathrm{K}$, and $\mathrm{P}$ content of the vegetation. Litter and soil organic matter in the barrens have a higher $\mathrm{C} / \mathrm{N}$ ratio than the forest. The Illinoian barrens Oa horizon is thicker and contains a greater quantity of exchangeable mineral nutrients than the other Oa horizons. Differences in vegetation nutrient capital strongly mirror differences in biomass. Our results show no strong association of parent material with soil or vegetation nutrient capital. Instead, they suggest that plant community characteristics, not soil nutrient availability, shape the landscape pattern of barrens and forest, particularly plant-driven positive feedbacks primarily involving fire frequency.
\end{abstract}

\section{Comments}

Copyright NRC Research Press. Published in Canadian Journal of Forest Research, Volume 34, Number 9, September 2004, pages 1819-1832.

Publisher URL: http://pubs.nrc-cnrc.gc.ca 


\title{
A biogeochemical analysis of the Pocono till barrens and adjacent hardwood forest underlain by Wisconsinan and Illinoian till in northeastern Pennsylvania
}

\author{
Anne W. Wibiralske, Roger Earl Latham, and Arthur H. Johnson
}

\begin{abstract}
We assessed soil and vegetation nutrient capital in the landscape mosaic of till barrens and hardwood forests on the Pocono Plateau in northeastern Pennsylvania. These shrublands, which contain an unusual abundance of rare species, occur primarily on Illinoian-aged glacial till, though some patches grow on Wisconsinan till. We hypothesized that barrens soil and vegetation contain smaller quantities of nutrients than forest soil and vegetation, and under the same vegetation, Illinoian till soils have a smaller nutrient content than Wisconsinan till soils. We measured $\mathrm{pH}$, total $\mathrm{C}$ and $\mathrm{N}$, and exchangeable $\mathrm{Ca}, \mathrm{Mg}, \mathrm{K}$, and $\mathrm{Al}$ content of the soils and determined $\mathrm{C}, \mathrm{N}, \mathrm{Ca}, \mathrm{Mg}, \mathrm{K}$, and $\mathrm{P}$ content of the vegetation. Litter and soil organic matter in the barrens have a higher $\mathrm{C} / \mathrm{N}$ ratio than the forest. The Illinoian barrens Oa horizon is thicker and contains a greater quantity of exchangeable mineral nutrients than the other Oa horizons. Differences in vegetation nutrient capital strongly mirror differences in biomass. Our results show no strong association of parent material with soil or vegetation nutrient capital. Instead, they suggest that plant community characteristics, not soil nutrient availability, shape the landscape pattern of barrens and forest, particularly plant-driven positive feedbacks primarily involving fire frequency.

Résumé : Nous avons évalué le stock de nutriments dans le sol et la végétation dans une mosaïque de paysage de tills improductifs et de forêts feuillues sur le Plateau Pocono dans le nord-est de la Pennsylvanie. Ces prairies boisées où on retrouve une abondance peu commune d'espèces rares occupent principalement le till glaciaire de l'Illinoien, bien que certains îlots se développent sur le till du Wisconsinien. Nous avons posé l'hypothèse que les sols improductifs et la végétation qu'ils supportent contiennent des quantités plus faibles de nutriments que le sol et la végétation de la forêt; et qu'avec une même végétation, les sols du till Illinoien ont un contenu en nutriments inférieur à ceux du till Wisconsinien. Nous avons mesuré le $\mathrm{pH}, \mathrm{C}$ et $\mathrm{N}$ totaux et $\mathrm{Ca}, \mathrm{Mg}$ et $\mathrm{K}$ échangeables et le contenu en $\mathrm{Al}$ des sols ainsi que le contenu en $\mathrm{C}, \mathrm{N}, \mathrm{Ca}, \mathrm{Mg}, \mathrm{K}$ et $\mathrm{P}$ de la végétation. La litière et la matière organique du sol dans les milieux improductifs ont un rapport $\mathrm{C} / \mathrm{N}$ plus élevé qu'en forêt. L'horizon Oa des milieux improductifs Illinoiens est plus épais et contient une plus grande quantité de nutriments échangeables que les autres horizons Oa. Les différences dans le stock de nutriments de la végétation reflètent bien les différences de biomasse. Nos résultats montrent qu'il n'y a pas de relation étroite entre le type de roche-mère et le stock de nutriments dans le sol ou dans la végétation. Au lieu de cela, ils suggèrent que les caractéristiques de la communauté végétale, et non la disponibilité en nutriments du sol, façonnent le type de paysage des terrains improductifs et de la forêt, particulièrement les rétroactions positives contrôlées par la végétation qui impliquent surtout la fréquence des feux.
\end{abstract}

[Traduit par la Rédaction]

\section{Introduction}

The Pocono till barrens stand in striking contrast, both in species composition and stature, to the adjacent northern hardwood and mixed hardwood - conifer forests, the predominant vegetation on the Pocono Plateau in northeastern Pennsylvania (Braun 1950). Dominated by scrub oak
(Quercus ilicifolia Wang.), sheep-laurel (Kalmia angustifolia L.), lowbush blueberries (Vaccinium angustifolium Ait., Vaccinium myrtilloides Michx., Vaccinium pallidum Ait.), and rhodora (Rhododendron canadense (L.) Torr.), the barrens typically have a shrub-savanna appearance with an open overstory of pitch pine (Pinus rigida P. Mill.). These shrublands occur as patches within the hardwood forest in a

Received 16 July 2003. Accepted 26 February 2004. Published on the NRC Research Press Web site at http://cjfr.nrc.ca on 16 September 2004.

A.W. Wibiralske, ${ }^{1,2}$ R.E. Latham, ${ }^{3}$ and A.H. Johnson. Department of Earth and Environmental Science, University of Pennsylvania, Philadelphia, PA 19104-6316, USA.

${ }^{1}$ Corresponding author (e-mail: wibiralske@hws.edu).

${ }^{2}$ Present address: Environmental Studies Program, Hobart and William Smith Colleges, Geneva, NY 14456, USA.

${ }^{3}$ Present address: Continental Conservation, P.O. Box 57, Rose Valley, PA 19086-0057, USA. 
40-km-long and approximately 1-km-wide swath along the southern edge of the Pocono Plateau, and are the largest single area of barrens vegetation in Pennsylvania (Latham et al. 1996; Latham 2003).

Several features of the Pocono till barrens distinguish them from other barrens. They are especially species-rich, including the highest concentration of globally rare plant and animal species in Pennsylvania (Davis et al. 1991) and many regionally rare, disjunct and edge-of-range populations (The Nature Conservancy, Middletown, Pennsylvania, unpublished data). Plants classified as wetland indicator species (Reed 1988) comprise a substantial portion of the till barrens flora, often growing side by side with vegetation more typically associated with xeric barrens (Latham et al. 1996). Unlike most barrens in eastern North America, which typically grow in excessively drained soils forming in sandy coastal plain and glacial outwash deposits or shallowto-bedrock substrates (Olsvig 1980; Homoya 1994; Anderson et al. 1999), more than half of the Pocono barrens (by area) grow in mesic soils forming in glacial till (Latham et al. 1996; Wibiralske 2002). Like many other persistent shrublands, these barrens also have a history of frequent wildfires (Latham et al. 1996).

During the 20th century, barrens on the Pocono Plateau experienced a dramatic conversion to forest. Approximately $65 \%$ of the area covered by barrens in 1938 had become forested by 1992 (Thompson 1995; Latham et al. 1996). Concerned about protecting the rich biodiversity of these shrublands and interested in understanding the processes that determine the occurrence of barrens or forest in the Pocono Plateau landscape, ecologists and conservationists have begun to explore the ecosystem dynamics that determine the presence and persistence of this unusual plant community. Previous studies of these barrens were undertaken by foresters, who concluded that converting the scrub oak groves to stands of merchantable timber was not economically feasible (Burnham et al. 1947; McQuilkin 1961). Recent research has focused on quantifying how the Pocono till barrens differ from neighboring forests and wetlands and exploring the relative importance of biotic and abiotic processes in influencing whether barrens or forest persist at a given location. Studies to date have investigated floristic patterns, plant species distributions, soil moisture, spatial and temporal dynamics of the barrens and adjacent forests, and plant nitrogen use (Thompson 1995; Latham et al. 1996; Eberhardt and Latham 2000; Latham 2003).

In their assessment of the vegetation, surficial geology, and fire history on the Pocono Plateau, Latham et al. (1996) reported a high correlation between till barrens and Illinoian till: $>90 \%$ of the Pocono till barrens are underlain by Illinoian-aged glacial till, one of the few large till deposits of this age (ca. 140000 years) in eastern North America (Crowl and Sevon 1980). A few patches of barrens $(<10 \%)$ also occur on Wisconsin-aged glacial till (ca. 15000 years), the prevalent till on the Pocono Plateau and across northern North America (Crowl and Sevon 1980; Crowl 1980). The U.S. Department of Agriculture, Soil Conservation Service has classified the soils forming in both tills as deep soils with a fine-loamy texture and high water-holding capacity (Fisher et al. 1962; Lipscomb 1981), properties in contrast with the sandy or shallow-to-bedrock and droughty charac- teristics typical of barrens soils elsewhere. Latham et al. (1996) found no difference between the barrens and forest in depth to seasonal high water table measured over 2 years with normal precipitation. Actual soil water content did not differ between barrens and adjacent forests during a later drought year (Eberhardt and Latham 2000). Although the Pocono till barrens soils appear to diverge from droughty character of the soils of most other barrens, the strong association of the Pocono barrens with soils formed in Illinoian-aged till suggests some soil control over vegetation. However, Latham et al.'s (1996) analysis of the vegetation growing in Illinoian till soils showed a more complex relationship between soil properties and vegetation type. They reported that barrens occupy only $23 \%$ of the Illinoian till on the Pocono Plateau, with upland hardwood forest covering $57 \%$ of the Illinoian till, cropland and high-density residential development covering $16 \%$, and wetlands covering the remaining $4 \%$.

In this paper, we describe a study designed to assess the association of soil and vegetation nutrient capital with plant community type and parent material (till) type. Following the conventional view of barrens soils, we hypothesized (1) that barrens soils would have lower nutrient concentrations and amounts than forest soils, and (2) that Illinoian till soils, having been exposed to weathering for a longer time (approximately 140000 years), would have lower nutrient concentrations and amounts than Wisconsinan till soils, which have been subjected to weathering for approximately 15000 years. Based on our observations in the field, we expected (3) that barrens vegetation contains a smaller quantity of nutrients than the adjacent forest vegetation, given the smaller stature and fewer trees in the barrens than in the forest. Following from (2), we further hypothesized (4) that, if available soil nutrients were exhibiting a strong influence on vegetation nutrient capital, then barrens and forests growing in Illinoian till soils would have smaller quantities of nutrients, respectively, than barrens and forests growing in Wisconsinan till soils.

\section{Study area}

The Pocono till barrens lie along the southern edge of the Pocono Plateau $\left(41^{\circ} 03^{\prime} \mathrm{N}, 75^{\circ} 30^{\prime} \mathrm{W}\right)$ in a flat to gently sloping landscape with a mean elevation of approximately $550 \mathrm{~m}$. The plateau has a cool, humid climate, with a mean annual rainfall of $129 \mathrm{~cm}$ (Owenby and Ezell 1992). At its maximum advance the Wisconsinan glacier covered about 85\% of the Pocono Plateau (Berg et al. 1989), blanketing this area with deposits of till, outwash, and ice-contact stratified drift. The terminal moraine of the Wisconsinan glacier forms a low ridge near the plateau escarpment. Dropping steeply $250-350 \mathrm{~m}$ into the neighboring Ridge and Valley Province (Berg et al. 1989), the escarpment marks the southern boundary of the plateau. South from the Wisconsinan terminal moraine to the escarpment, the plateau has a complex surficial geology composed mainly of material weathered from sandstone and conglomerate bedrock of the Devonian Catskill Formation, with several small areas of alluvium, peat, and muck deposits and a few large areas of Illinoian glacial till (Berg et al. 1977; Sevon 1975a, 1975b; Latham et al. 1996). 
In a $406-\mathrm{km}^{2}$ area, which includes nearly all of the barrens on the southern Pocono Plateau, Latham et al. (1996) mapped current vegetation patterns based on aerial photograph interpretation with ground-truthing. Upland forests constitute about $300 \mathrm{~km}^{2}(75 \%)$ of the study area and grow in each of the surficial substrate types. American beech (Fagus grandifolia Ehrh.), red maple (Acer rubrum L.), and black cherry (Prunus serotina Ehrh.) typically dominate these northern hardwood and mixed hardwood - conifer forests. Other canopy species commonly occurring in these forests include sugar maple (Acer saccharum L.), yellow birch (Betula alleghaniensis Britt.), sweet birch (Betula lenta L.), northern red oak (Quercus rubra L.), eastern hemlock (Tsuga canadensis (L.) Carr.), eastern white pine (Pinus strobus L.), and red spruce (Picea rubens Sarg.). Barrens cover about $42 \mathrm{~km}^{2}(10 \%)$ of this area in many small and several large patches in distinct subtypes identified by the dominant shrub or tree species. Pitch pine forests and woodlands represent a small portion of the barrens. Most of the barrens, in varying proportions, are composed of three shrub-dominated subtypes: scrub oak barrens, rhodora barrens, and heath barrens (dominated by sheep-laurel and lowbush blueberries). More than a dozen shrub species in the family Ericaceae, mainly sheep-laurel, the blueberries, and rhodora, are present in each of the subtypes in different degrees of abundance. The remainder of the study area is covered by wetlands, open water, cultivated fields, and artificial fill.

Two broad categories of barrens occur on the Pocono Plateau. About $43 \%\left(18 \mathrm{~km}^{2}\right)$ are xeric scrub oak barrens with few ericaceous plants. They grow on shallow, sandy soils weathered from the Devonian bedrock and are typical of barrens growing in shallow-to-bedrock soils atop the summits and ridges of the Appalachian Mountains. The remaining $57 \%\left(24 \mathrm{~km}^{2}\right)$ of the barrens grow on mesic, loamy soils and contain both xeric and wetland plants with ericaceous shrubs comprising a high proportion of the species in each barrens subtype. Nearly all $\left(22 \mathrm{~km}^{2}\right)$ of the mesic barrens are underlain by glacial till, with a small portion $\left(2 \mathrm{~km}^{2}\right)$ underlain by alluvial deposits. About $91 \%\left(20 \mathrm{~km}^{2}\right)$ of the till barrens grow on Illinoian till deposits, and about $9 \%\left(2 \mathrm{~km}^{2}\right)$ grow on Wisconsinan till. In this study we focus on the shrub-dominated barrens growing in glacial till. The soils forming in the till deposits are deep, gravelly to stony, silt loams that typically have a fragipan at about $45 \mathrm{~cm}$ below the surface in the Illinoian till soils and $25 \mathrm{~cm}$ in Wisconsinan till, and these soils are described as very strongly to extremely acidic (Fisher et al. 1962; Lipscomb 1981). The common soil series at the Illinoian till sites include $\mathrm{Bu}-$ chanan (Aquic Fragiudult), Clymer (Typic Hapludult), and Alvira and Watson (Typic Fragiaquult, Aeric Fragiaquult). The common soil series at the Wisconsinan till sites include Wellsboro (Typic Fragiudept), Morris (Aeric Fragiaquept), and Chippewa and Norwich (Typic Fragiaquepts) (Fisher et al. 1962; Lipscomb 1981; Soil Survey Staff [online]).

\section{Materials and methods}

We sampled soil in 99 plots and sampled and measured trees and large shrubs, small woody and herbaceous plants, and coarse roots in 63 plots. These plots encompass the four combinations of parent material (Illinoian and Wisconsinan till) and plant community type (barrens and forest) in our study and were sampled during the summer months of 1992 and 1993, with tree height and diameter measurements in some forested plots made after leaf fall. The plots were randomly located at eight sites in Monroe and Carbon Counties in northeastern Pennsylvania (Fig. 1). None of these sites shows evidence of past plowing (no Ap horizon). Using field-based observations we categorized the plots as forest or barrens, and further categorized the barrens plots as scrub oak, heath, or rhodora barrens.

Our field-based categorizations of the barrens subtypes matched well with a classification using the computer program CANOCO's two-way indicator species analysis (TWINSPAN), which included our plots (Latham et al. 1996). In the few instances where our field-based classification differed from the TWINSPAN classification, we retained the field-based classifications, because we felt they better represented the dominant vegetation around our soil pits. We did not distinguish between northern hardwood and mixed hardwood - conifer forests, thus our forest category has no subcategories. Because nearly all of the barrens growing in Wisconsinan till are heath barrens and virtually all occur at one site, our category of Wisconsinan barrens also has no subcategories and could not be replicated. In Illinoian barrens we sampled soil and vegetation in all three shrub barrens subtypes, but treated Illinoian barrens as a single category containing plots from all three Illinoian barrens subcategories.

\section{Soil and coarse root sampling}

Sixty-two of the soil pits were located at the center of long-term vegetation plots. In $50 \mathrm{~cm} \times 50 \mathrm{~cm}$ pits we quantitatively sampled the Oi and Oe horizons combined and the Oa horizon in $25 \mathrm{~cm} \times 25 \mathrm{~cm}$ subsamples, and we measured and sampled the mineral soil in layers at depths of $0-10$, 10-20, and $20-50 \mathrm{~cm}$, using the quantitative soil pit method described by Hamburg (1984). From the bottom of the soil pits, we cored to an additional $30-\mathrm{cm}$ depth in two increments $(50-65$ and $65-80 \mathrm{~cm})$ using a 5-cm-diameter soil corer. The 0 - to $10-\mathrm{cm}$ layer included the A horizon and usually the upper part of the B horizon, which typically had a dark brown color from accumulation of humus and iron oxides leached from above. The 10- through 80-cm depths were all within the $\mathrm{B}$ horizon. In the field, using a $12.5-\mathrm{mm}$ sieve, we separated coarse roots and rocks from the mineral soil. In the lab, we used a 5-mm sieve to separate the coarse roots from the Oa horizon. All root samples were washed briefly with deionized water to remove humus and mineral soil and then oven-dried at $80{ }^{\circ} \mathrm{C}$ to a constant mass.

From the remaining 37 soil pits, $15 \mathrm{~cm} \times 15 \mathrm{~cm}$ in size, we quantitatively collected the $\mathrm{Oi}$ and Oe horizons combined, the Oa horizon, and the 0 - to $10-\mathrm{cm}$ layer of mineral soil. From the bottom of the 0 - to $10-\mathrm{cm}$ layer, we cored 10to $20-\mathrm{cm}$ and $20-$ to $50-\mathrm{cm}$ depths using a $5-\mathrm{cm}$-diameter soil corer. We concentrated our sampling effort in the upper $50 \mathrm{~cm}$ of the mineral soil, which, in these soils, typically includes the root zone and the top of the fragipan.

\section{Soil sample analysis}

We analyzed the $<5-\mathrm{mm}$ fraction of the Oa horizon and the $<2-\mathrm{mm}$ fraction of the mineral soil layers for exchangeable $\mathrm{Ca}, \mathrm{Mg}, \mathrm{K}$, and $\mathrm{Al}$ by extraction of air-dry soils with 
Fig. 1. Surficial geology of the southern Pocono Plateau with soil and vegetation sampling site locations and boundary of the study area for Latham et al. (1996) (data from Berg et al. 1977; Sevon 1975a, 1975b; Crowl and Sevon 1980; Latham et al. 1996).

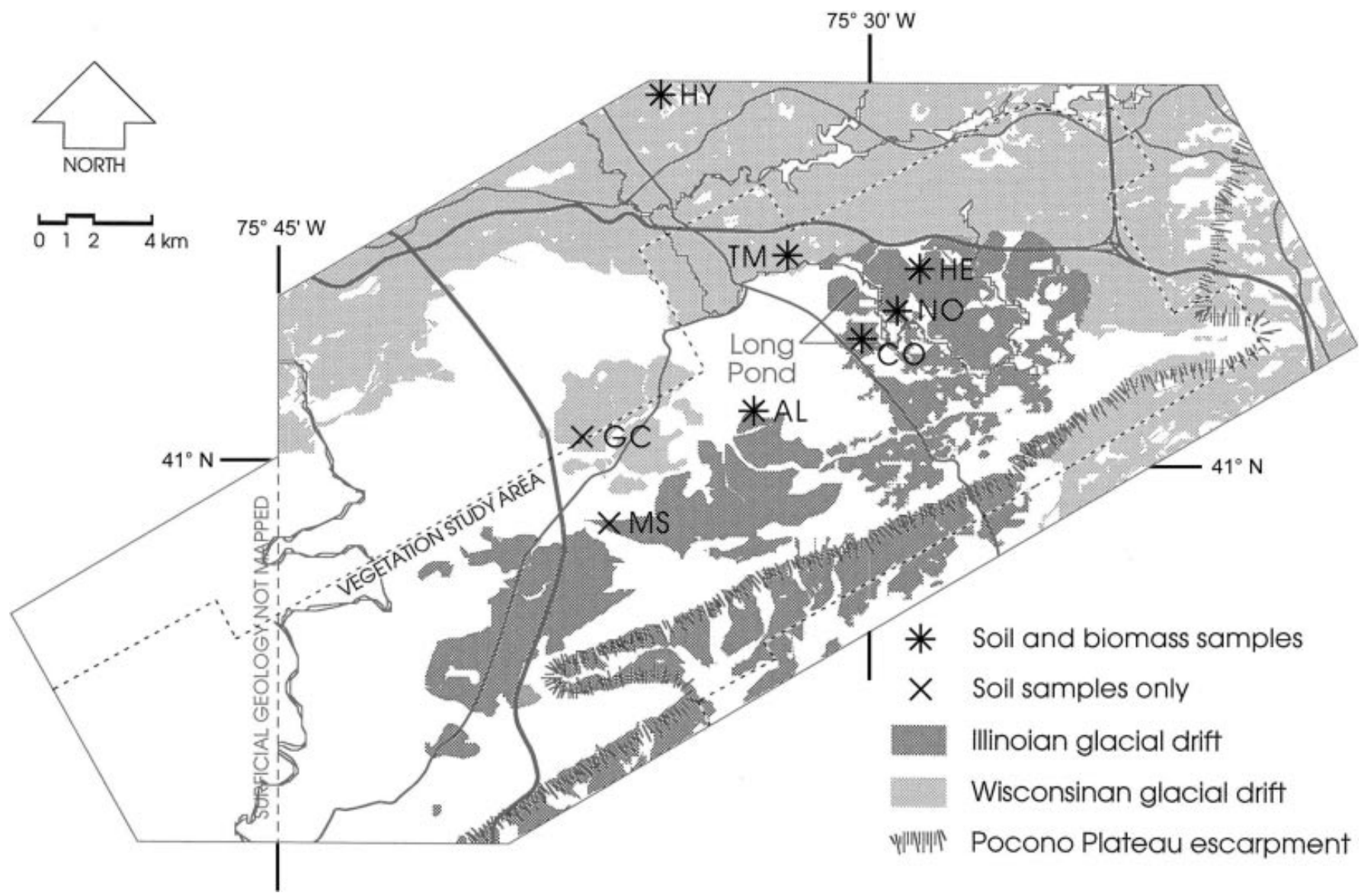

$1 \mathrm{~mol} / \mathrm{L} \mathrm{NH}_{4} \mathrm{Cl}$ and elemental analysis by inductively coupled plasma (ICP) emission spectrometry (Robarge and Fernandez 1987). The combined Oi and Oe samples were ground and analyzed for total concentrations of the same elements (except Al) by dry-ashing and concentrated hydrochloric and hydrofluoric acid digestion (Robarge and Fernandez 1987), with elemental analysis by ICP.

We measured the $\mathrm{C}$ and $\mathrm{N}$ concentration of all soil samples, mineral and organic, using a Carlo Erba elemental analyzer and standard operating procedures (Fisons Instruments NA1500, Dearborn, Michigan). The soils are sufficiently acidic to eliminate the presence of inorganic C. Results of mineral soil reference samples consistently fell within $20 \%$ of the long-term mean values established in our laboratory, and organic matter reference materials were consistently within 5\% of reference values. We measured $\mathrm{pH}$ in a solution of deionized water and soil with a 1:1 ratio by volume for the mineral soils and a 2:1 ratio by volume for organic horizons. To convert element concentrations $\left(\mu \mathrm{g} \cdot \mathrm{g}^{-1}\right)$ and percent $\mathrm{C}$ and $\mathrm{N}$ of the soil samples to nutrient content $\left(\mathrm{kg} \cdot \mathrm{ha}^{-1}\right)$, we used bulk-density estimates based on $105{ }^{\circ} \mathrm{C}$ oven-dry mass conversions of field masses of the quantitatively sampled soils. Because of the difficulty in quantitatively coring into the fragipan in the deeper layers and the resulting smaller sample size for these layers, we report soil nutrient content results to a depth of $50 \mathrm{~cm}$ in the mineral soil. We interpret these data with caution, because some of the data do not have normal distributions.

\section{Tree and large-shrub sampling}

Around the plot centers of 63 of our long-term vegetation plots, we established concentric $200-\mathrm{m}^{2}$ and $400-\mathrm{m}^{2}$ circular plots. Within the $400-\mathrm{m}^{2}$ plot, we measured the height and diameter at breast height $(\mathrm{DBH})$ of all woody vegetation $\geq 10 \mathrm{~cm}$ DBH. Within the $200-\mathrm{m}^{2}$ plot, we measured the height and DBH of all woody vegetation $\geq 2 \mathrm{~cm} \mathrm{DBH}<10 \mathrm{~cm}$. Using published allometric equations (Whittaker and Woodwell 1968; Tritton and Hornbeck 1982; Ter-Mikaelian and Korzukhin 1997), we estimated tree and large-shrub biomass from DBH and height measurements. When several equations were available, we chose the equation from the location most similar to our study site that included the range of $\mathrm{DBH}$ measurements in our data set. For species with no available equations, we used multispecies equations that included species of comparable growth forms and stature. We collected foliage and bole tissue from the 13 most abundant species in our tree and large-shrub plots. These 13 species account for the following mean percent of plot biomass: $98 \%$ for Illinoian barrens, $80 \%$ for Wisconsinan barrens, $95 \%$ for Illinoian forests, and $89 \%$ for Wisconsinan forests.

\section{Small woody and herbaceous plant sampling}

In four $50 \mathrm{~cm} \times 50 \mathrm{~cm}$ quadrats in the 63 vegetation plots, we harvested all aboveground vegetation $<2 \mathrm{~cm}$ DBH. Three of the quadrats were located $7 \mathrm{~m}$ from the plot center along a bearing of $45^{\circ}, 135^{\circ}, 225^{\circ}$, or $315^{\circ}$. The fourth was lo- 
cated adjacent to the plot center at the site of the $50 \mathrm{~cm} \times$ $50 \mathrm{~cm}$ quantitative soil pit dug in these plots. As we harvested the vegetation, we separated it into three categories: woody, herbaceous, and dead vegetation.

\section{Plant tissue nutrient analysis}

All plant tissue samples were oven-dried to a constant mass at $80{ }^{\circ} \mathrm{C}$ and ground for nutrient analysis. We measured the $\mathrm{C}$ and $\mathrm{N}$ concentration using a Carlo Erba elemental analyzer and standard operating procedures (Fisons Instruments NA1500, Dearborn, Michigan). To measure Ca, $\mathrm{Mg}, \mathrm{K}$, and $\mathrm{P}$ concentration, we processed the samples by dry-ashing and concentrated hydrochloric acid digestion and performed elemental analysis by ICP. Reference material results were consistently within $10 \%$ of the reference values.

\section{Statistical analysis}

To compare the mean values of each element measured in the soil and plant tissue samples, we used a two-way analysis of variance (ANOVA) model including parent material and plant community type as main effects and the parent material $\times$ community type interaction effect. With this model we tested the following hypotheses:

1. $\mu_{\text {(barrens soil/plant tissue) }}<\mu_{\text {(forest soil/plant tissue) }}$ or for small vegetation: $\mu_{\text {(barrens plant tissue) }}>\mu_{\text {(forest plant tissue) }}$

2. $\mu_{\text {(Illinoian till soil/plant tissue })}<\mu_{\text {(Wisconsinan till soil/plant tissue) }}$

where $\mu$ corresponds to the mean value of the soil or plant tissue variable described by the subscript. When our data did not meet the assumptions of ANOVA, we used the nonparametric Scheirer-Ray-Hare extension of the Kruskal-Wallis test for ranked data (Sokal and Rohlf 1995). We considered main or interaction effects to be significant when the probability of $F$ or $H$ was $<0.05$. Since our main effects each contain only two categories, post-hoc analysis is not necessary to identify the source of significant main effects. When the parent material $\times$ community type interaction was significant, we used the Tukey test (Sokal and Rohlf 1995) to make post-hoc comparisons and identify the source of the interaction effect. When the probability of $q$ was $<0.05$, we considered pairs of means to be significantly different. Where an interaction effect was significant when we used ANOVA on ranks, we did not statistically analyze these data further, because a nonparametric post-hoc test for data sets with unequal sample sizes is not available. Because the random variable "site" in our data set is highly correlated with the fixed variables parent material and plant community type, we are unable to meaningfully test for site effects. Thus, we interpret our results with caution, recognizing that the possibility of a significant site effect has not been eliminated from our analysis.

Since the tree and large-shrub plot-level biomass estimates are sums of biomass estimates of individual stems, and usually of several different species, the error for these biomass estimates is not readily quantifiable. We have not analyzed these data using ANOVA. However, we do report the mean and standard error of the mean for estimated tree and large-shrub biomass and nutrient content $\left(\mathrm{kg} \cdot \mathrm{ha}^{-1}\right)$ for each category, recognizing that the standard errors reported are minimum-error values.
The concentration of exchangeable $\mathrm{Ca}$ and $\mathrm{K}$ in many of our mineral soil samples and the concentration of total $\mathrm{P}$ in some of our tree bole samples fell below the detection limit of the ICP. When most samples within a category fell below the detection limit, we did not statistically analyze these data. If only a few samples within a category fell below the detection limit, we used the value halfway between the detection limit and zero for those samples when calculating their $\mathrm{Ca}, \mathrm{K}$, or $\mathrm{P}$ content.

\section{Results}

Strong support for our first two hypotheses about soil nutrient content requires a consistent pattern throughout the soil profile, where barrens and Illinoian till are associated with lower soil nutrients than forest and Wisconsinan till. Our soil nutrient results either have no significant community type and parent material effects, or, where significant, the community type and parent material effects are not continuous through the depth of the soil profile and, most importantly, are in the opposite direction from our predictions. The vegetation nutrient results follow our field observations: we found a larger biomass and nutrient content in trees and large shrubs in the forest than in barrens, and a larger biomass and nutrient content in small shrubs in barrens than in the forest. Coarse roots are differently distributed with depth between the barrens and forest, but total coarse root biomass and nutrient content, except for $\mathrm{P}$, are similar. In keeping with our soil data, the vegetation results show no clear or consistent significant parent material effects associated with plant tissue nutrient capital.

\section{Soil nutrient analysis}

Our $\mathrm{C} / \mathrm{N}$ ratio data come the closest to a consistent result throughout the soil profile. From the Oi-Oe horizons to a depth of $20 \mathrm{~cm}$ in the mineral soil, the $\mathrm{C} / \mathrm{N}$ ratio is greater in soil under barrens than forest, and from $20-80 \mathrm{~cm}$, the $\mathrm{C} / \mathrm{N}$ ratio is higher in Wisconsinan till soils than Illinoian till soils (Fig. 2). Forest soils have a greater $\mathrm{N}$ content in the mineral soil than barrens soils, but $\mathrm{N}$ content does not show a clear pattern in the organic horizons (Fig. 3). None of the other nutrient profiles shows a consistent parent material, community type, or interaction effect throughout the depth of the soil profile. However, $\mathrm{Ca}$ concentration and content have a significant plant community type effect in the upper portion of the soil profile with barrens soils having a higher Ca concentration and content than forest soils (Figs. 4 and 5). In the lower portion of the $\mathrm{pH}$ profile there are significant parent material effects where Illinoian till soils have a higher $\mathrm{pH}$ than Wisconsinan till soils (Fig. 6).

\section{Soil mass}

The dominant feature in the organic horizons is the significantly larger mass of the Oa horizon in Illinoian barrens soil than in the Wisconsinan barrens soil and in both forest soils (Table 1). The Illinoian barrens $\mathrm{Oa}$, at two to three times the mass of the other three categories, drives the significant main and interaction effects for this horizon in all the nutrient content profiles, with the Illinoian barrens having a significantly larger content of each element measured than the other three categories. The similar $\mathrm{C}$ concentration of about 
Fig. 2. Mean $\mathrm{C} / \mathrm{N}$ ratio of the $\mathrm{Oi}-\mathrm{Oe}$ and $\mathrm{Oa}$ horizons and of the 0 - to $10-, 10-$ to $20-, 20-$ to $50-, 50-$ to $65-$, and $65-$ to $80-\mathrm{cm}$ mineral soil layers. F, forest; B, barrens; I, Illinoian till; W, Wisconsinan till; *, ANOVA on ranks; ${ }^{\dagger}$, significant interaction effect with no post-hoc analysis. Error bars are \pm 1 SE.

\section{C:N ratio}

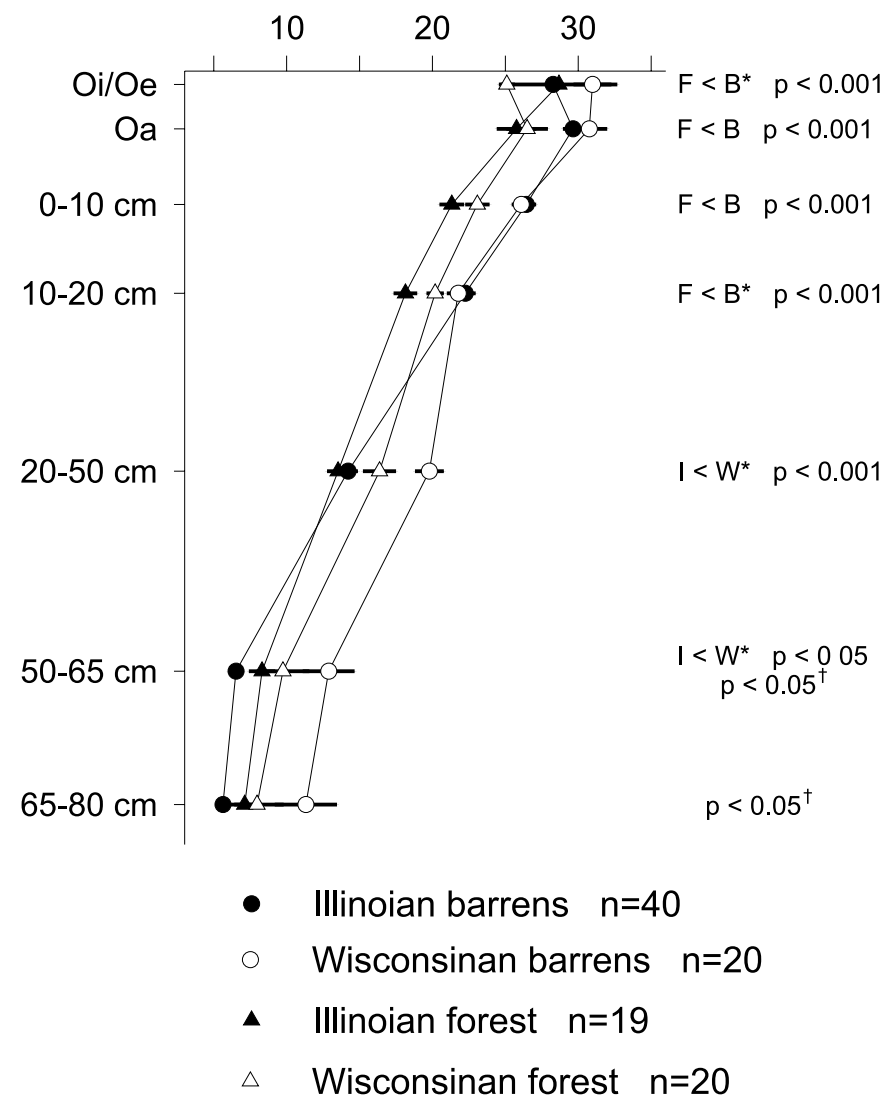

$25 \%$ in each of the Oa horizons indicates that each Oa horizon contains the same proportion (approximately 50\%) of organic matter (Table 1).

The mass of the mineral soil ( $<2 \mathrm{~mm}$ fraction) to a depth of $50 \mathrm{~cm}$ is greater in Illinoian till soils, particularly Illinoian forest soils, than in Wisconsinan till soils and barrens soils (Table 1). However, bulk density is not significantly different among these soils (Table 1).

\section{Trees and large shrubs}

As is obvious, the forest has a much larger tree and large-shrub biomass than the barrens (Fig. 7). Illinoian barrens have about twice the leaf and wood mass of Wisconsinan barrens. The barrens and forest have proportionately similar amounts of leaf, wood, and dead wood mass. Leaf mass constitutes $4 \%-6 \%$ of the live biomass and stems and branches constitute 94\%-96\%. Dead wood constitutes $2 \%-3 \%$ of total tree and large-shrub biomass.

Tree and large-shrub nutrient content follows a similar pattern to biomass, with Illinoian and Wisconsinan forests having similar quantities of each nutrient, and the barrens containing considerably lower quantities (Figs. 3, 5, and 8). Illinoian barrens have about twice the nutrient content in leaves and wood as Wisconsinan barrens, except for foliar $\mathrm{Mg}$ content, which is about the same for both barrens.

Of the 13 tree and shrub species we analyzed for nutrient concentration, 4 (red maple, downy serviceberry (Amelanchier arborea (Michx. f.) Fern.), Allegheny serviceberry (Amelanchier laevis Wiegand.), and gray birch (Betula populifolia Marsh.) occur in all four parent material and plant community type categories. None of these species shows a consistent parent material or interaction effect for nutrient concentration (Table 2). However, red maple and gray birch wood have lower concentrations of some nutrients in the forest than in the barrens. The remaining nine species occur primarily in either barrens or forest and rarely or not at all in the other community and have no consistent significant effects.

\section{Small woody and herbaceous plants}

The small-vegetation biomass follows the predicted pattern of a significant community type effect. Barrens have a much greater live small woody vegetation biomass than forests and a greater standing dead small-plant biomass, which contains both dead woody and dead herbaceous vegetation (Fig. 7). Our measurement of standing dead biomass is a minimum estimate, since dead branches on live stems are included with live biomass measurements. The standing dead small-plant biomass in the Illinoian forest is much larger than in the Wisconsinan forest. However, the total live and dead small-vegetation biomass in the forest is similar. All categories have high standard errors. This variability is not surprising, given the patchiness in both species composition and abundance of the small vegetation across the Pocono Plateau landscape. Nonetheless, we interpret these data with caution, because some of the data are not normally distributed.

Herbaceous vegetation biomass shows a significant parent material effect, with more herbaceous vegetation on Illinoian till than on Wisconsinan till. On a percentage basis, however, herbaceous biomass is associated with community type. In the barrens, $3 \%-5 \%$ of the small-vegetation total biomass (live + dead) is in live herbaceous plants, whereas the corresponding value in the forest is $12 \%-15 \%$. Barrens total small-vegetation biomass is about four times greater than that of the forest (Fig. 7). Nutrient content of the small vegetation mirrors the biomass relationships described above.

\section{Coarse roots}

Coarse root biomass also has a clear pattern of significant plant community type effects, with greater coarse root mass near the soil surface in barrens and, deeper in the soil profile, a greater root mass in the forest (Fig. 9). The total coarse root mass through the depth of the rooting zone, however, is not significantly different between barrens and forest (Fig. 7). The high standard errors of the root mass means reflect a degree of variability among samples that is consistent with the patchiness of the vegetation, particularly small shrubs, in this landscape. Again, we interpret these data with caution, because some of the data do not have normal distributions.

Coarse-root nutrient content has a similar distribution between the upper and lower soil profile as that of root bio- 
Fig. 3. Mean $\mathrm{N}$ content $\left(\mathrm{kg} \cdot \mathrm{ha}^{-1}\right)$ in trees and large shrubs, small woody and herbaceous plants, coarse roots, and Oi-Oe horizons, and mean exchangeable $\mathrm{N}$ content $\left(\mathrm{kg} \cdot \mathrm{ha}^{-1}\right)$ in the Oa horizon and mineral soil to a depth of $50 \mathrm{~cm}$. IB, Illinoian barrens; WB, Wisconsinan barrens; IF, Illinoian forest; WF, Wisconsinan forest; F, forest; B, barrens; I, Illinoian till; W, Wisconsinan till; NS, not significant; $*$, ANOVA on ranks; ${ }^{\dagger}$, significant interaction effect with no post-hoc analysis. Error bars are \pm 1 SE.

\section{Nitrogen}

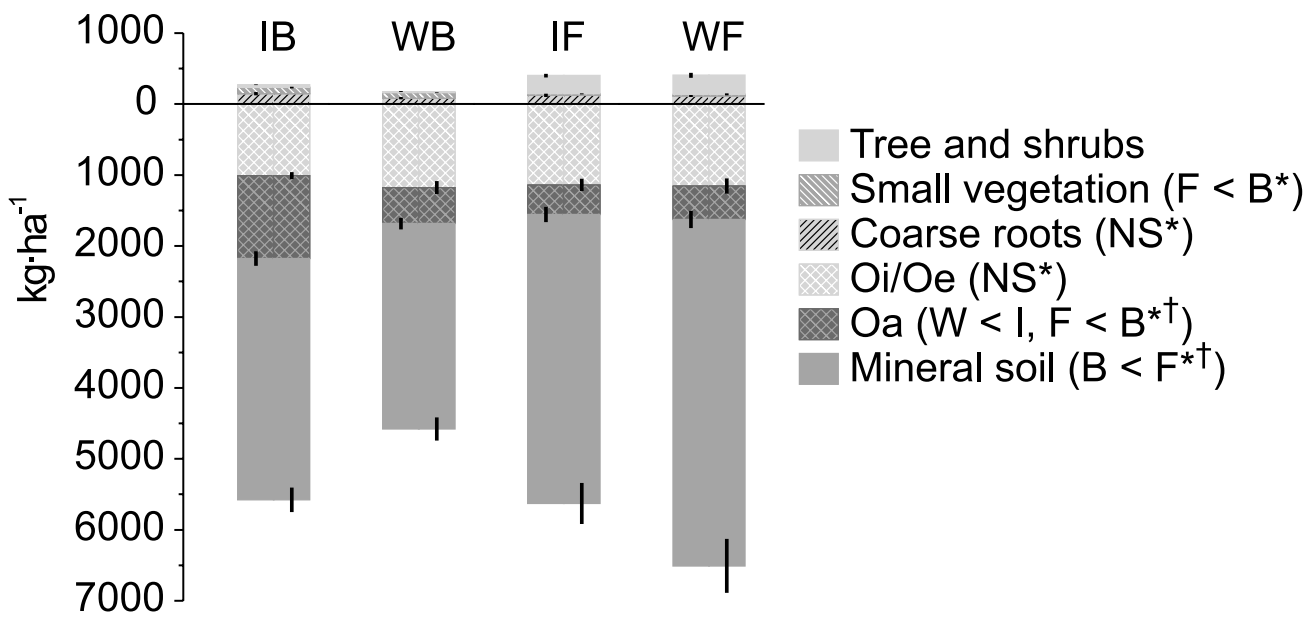

Fig. 4. Mean concentration $\left(\mu \mathrm{g} \cdot \mathrm{g}^{-1}\right)$ of total $\mathrm{Ca}$ in the Oi-Oe horizons and exchangeable $\mathrm{Ca}$ concentration $\left(\mu \mathrm{g} \cdot \mathrm{g}^{-1}\right)$ in the Oa horizon and mineral soil. Ca concentration of samples $10 \mathrm{~cm}$ and deeper fell below the detection limit of the inductively coupled plasma emission spectrometer and were not statistically analyzed. F, forest; B, barrens; I, Illinoian till; W, Wisconsinan till; *, ANOVA on ranks; $\dagger$, significant interaction effect with no post-hoc analysis. Error bars are $\pm 1 \mathrm{SE}$.

\section{Calcium}

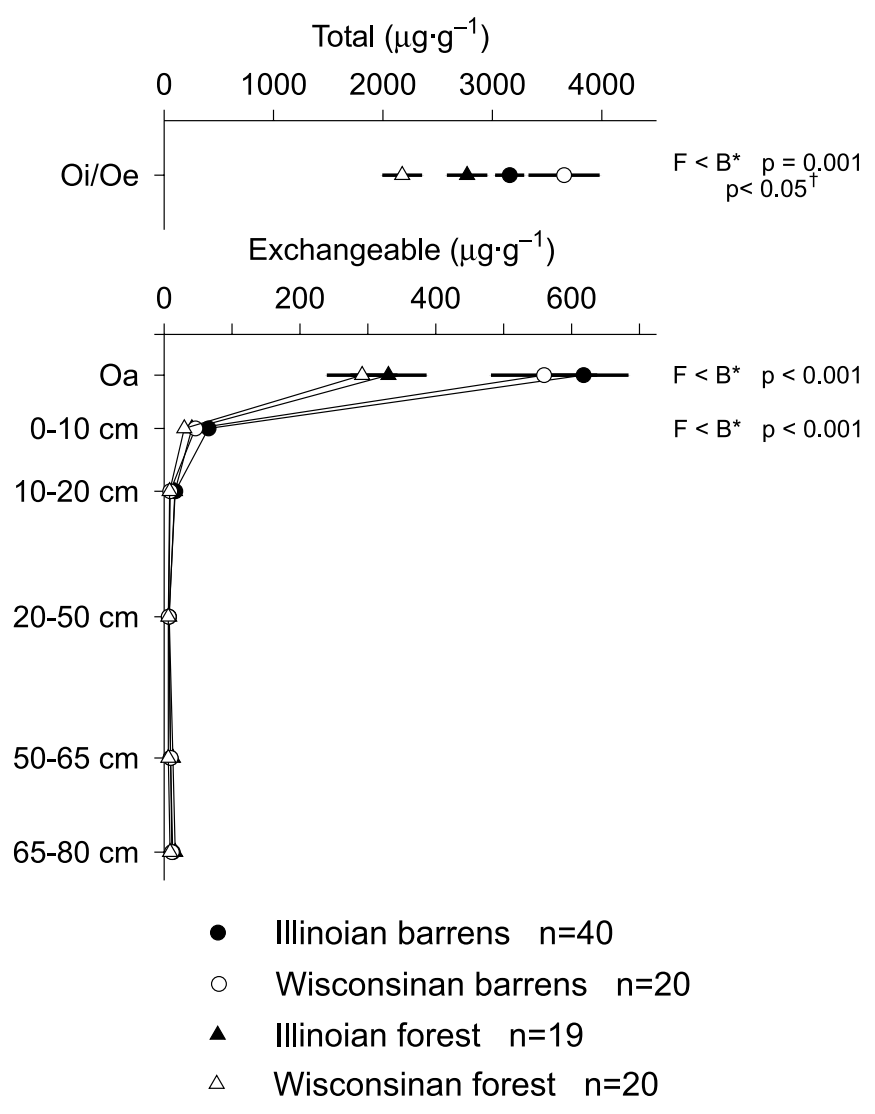

mass. The nutrient quantities in the sum of coarse roots within the root zone are not significantly different, except for P. Our analysis of total root $\mathrm{P}$ shows a significant interaction effect. Keeping in mind that some of the data are not normally distributed, comparing the means and standard errors of the mean suggests that Illinoian barrens roots contain a significantly larger amount of $\mathrm{P}$ than the other three categories.

\section{Discussion}

We draw two sets of conclusions from our analyses of soil and vegetation nutrient capital in the Pocono barrens and forest. First, our data do not support our initial hypotheses about low soil nutrients driving the distribution of barrens vegetation. Second, our results suggest a more complex relationship where barrens and forest vegetation modify the nutrient content in the upper portion of the soil profile. We propose that the differences in soil properties between forest and barrens involve the fire history of the region and suggest that the physical and chemical characteristics of the dominant plants in the two community types play a key role in modifying the frequency and severity of fire in their respective environments (Latham et al. 1996; Petraitis and Latham 1999). The influence of the dominant plants of the barrens and forest on fire dynamics may be more important than the soil nutrient content inherited from parent material in determining the presence and persistence of each community type at specific locations on the landscape.

\section{Subsoil dynamics}

In the soil profile, the upper portion tends to have significant plant community type effects, and the lower portion tends to show significant parent material effects. We interpret the relationships between community type and soil properties of the upper layers as plant-driven changes in soils rather than soil effects on plant species distributions, which we discuss below. The weak to nonexistent associa- 
Fig. 5. Mean Ca content $\left(\mathrm{kg} \cdot \mathrm{ha}^{-1}\right)$ in trees and large shrubs, small woody and herbaceous plants, coarse roots, and Oi-Oe horizons and mean exchangeable $\mathrm{Ca}$ content $\left(\mathrm{kg} \cdot \mathrm{ha}^{-1}\right)$ in the Oa horizon and mineral soil to a depth of $10 \mathrm{~cm}$. IB, Illinoian barrens; WB, Wisconsinan barrens; IF, Illinoian forest; WF, Wisconsinan forest; F, forest; B, barrens; I, Illinoian till; W, Wisconsinan till; NS, not significant; $*$, ANOVA on ranks; ${ }^{\dagger}$, significant interaction effect with no post-hoc analysis. Error bars are \pm 1 SE.

\title{
Calcium
}

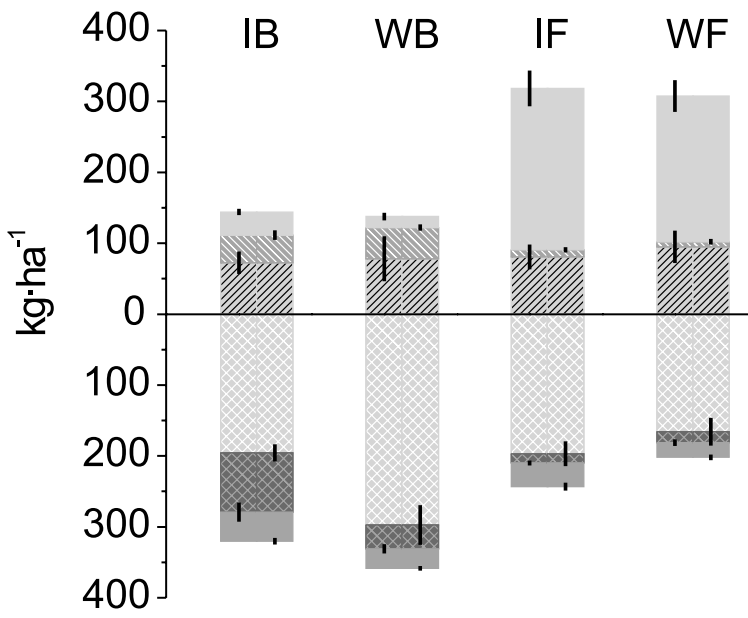

\author{
Tree and shrubs \\ Small vegetation $\left(\mathrm{F}<\mathrm{B}^{*}\right)$ \\ VI//. Coarse roots $\left(\mathrm{NS}^{*}\right)$ \\ $\mathrm{Oi} / \mathrm{Oe}\left(\mathrm{F}<\mathrm{B}^{*+}\right)$ \\ $\mathrm{Oa}\left(\mathrm{F}<\mathrm{B}^{*}\right)$ \\ $0-10 \mathrm{~cm}$ mineral soil $\left(\mathrm{W}<\mathrm{I}, \mathrm{F}<\mathrm{B}^{*}\right)$
}

Fig. 6. Mean $\mathrm{pH}$ of the $\mathrm{Oi}-\mathrm{Oe}$ and $\mathrm{Oa}$ horizons and of the $0-$ to $10-, 10$ - to 20-, 20- to 50-, 50- to 65-, and 65- to 80-cm mineral soil layers. F, forest; B, barrens; I, Illinoian till; W, Wisconsinan till; IB, Illinoian barrens; WB, Wisconsinan barrens; IF, Illinoian forest; WF, Wisconsinan forest; *, ANOVA on ranks; ${ }^{\dagger}$, significant interaction effect with no post-hoc analysis. Error bars are $\pm 1 \mathrm{SE}$.

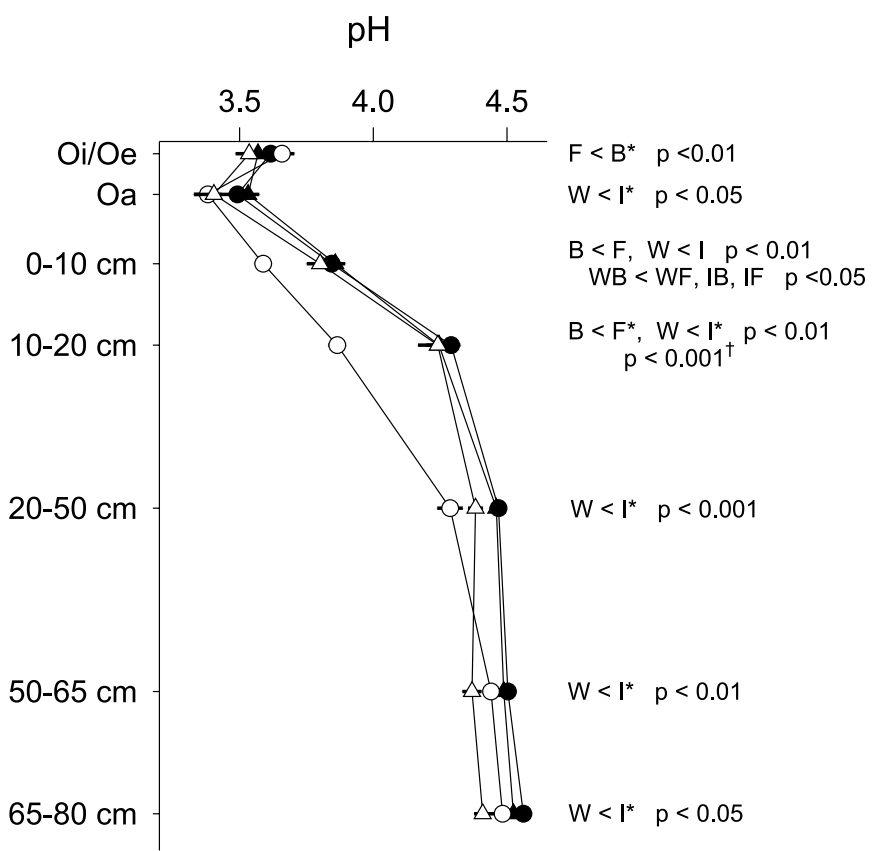

- Illinoian barrens $n=40$

- Wisconsinan barrens $n=20$

- Illinoian forest $\mathrm{n}=19$

$\triangle$ Wisconsinan forest $n=20$

tion of community type and parent material with soil properties in the lower layers suggests no influence, or at most, a very limited influence of parent material on the spatial pat- tern of plant communities and refutes the prediction of greater loss of nutrients from leaching in the older Illinoian till soils. Evidence is scant to explain why the Illinoian till subsoils contain slightly greater amounts of some nutrients. The Wisconsinan till mineral soils contain more rocks than Illinoian till mineral soils (Wibiralske 2002), thus we see a larger mass per unit surface area of $<2 \mathrm{~mm}$ soil formed on Illinoian till compared with the Wisconsinan till. The greater mass of Illinoian till soil explains in part its larger nutrient content.

Though there are typically argillic horizons in the Ultisols on Illinoian till, the textural classes of the subsoils on the two till types differ very little. The B horizons of most soil series on both tills are silt loams or loams, with the only clay loam associated with the subsoil of the Watson series (see soil descriptions at http://soils.usda.gov/technical/classification/osd/ index.html or in Fisher et al. (1962) and Lipscomb (1981)), which makes up a very small portion of Illinoian till soils and is a very minor component at only one of our study sites (Fisher et al. 1962; Lipscomb 1981). Argillic horizons indicate greater weathering and clay accumulation, but our data do not provide evidence of nutrient removal, despite the large difference in the time these profiles have been subjected to pedogenic processes. We postulate that the small differences in nutrient concentration and content we have found between the tills, even though statistically significant, are probably too small to control the distribution of plant species and thus do not play an important role in influencing the presence and persistence of barrens or forest.

\section{Organic matter and upper soil dynamics}

The quantity of organic matter in the organic and mineral horizons and the quality of organic matter as expressed in the $\mathrm{C} / \mathrm{N}$ ratio appear to be responding to the composition of the overlying plant community. The consistent mass and $\mathrm{C}$ and $\mathrm{N}$ content in the Oi-Oe horizons of barrens and forests growing on both till types suggest a similar accumulation of organic matter on the ground surface. The higher $\mathrm{C} / \mathrm{N}$ ratio in 
Table 1. Soil mass $\left(\mathrm{Mg} \cdot \mathrm{ha}^{-1}\right)$, bulk density $\left(\mathrm{g} \cdot \mathrm{cm}^{-3}\right)$, and \% carbon of barrens and forest soils on Illinoian (Ill.) and Wisconsinan (Wisc.) glacial till deposits on the Pocono Plateau in Monroe and Carbon counties in northeastern Pennsylvania.

\begin{tabular}{|c|c|c|c|c|c|c|c|c|c|}
\hline \multirow[b]{2}{*}{ Horizon or soil layer } & \multicolumn{2}{|c|}{ Ill. barrens $(n=40)$} & \multicolumn{2}{|c|}{ Wisc. barrens $(n=20)$} & \multicolumn{2}{|c|}{ Ill. forest $(n=19)$} & \multicolumn{2}{|c|}{ Wisc. Forest $(n=20)$} & \multirow[b]{2}{*}{ ANOVA results } \\
\hline & Mean & SE & Mean & SE & Mean & SE & Mean & SE & \\
\hline \multicolumn{10}{|l|}{ Soil mass $\left(\mathrm{Mg} \cdot \mathrm{ha}^{-1}\right)$} \\
\hline $\mathrm{Oa}$ & 136.0 & 11.7 & 65.5 & 10.2 & 43.6 & 11.6 & 52.1 & 13.0 & $\mathrm{~F}<\mathrm{B} * \dagger$ \\
\hline $0-10 \mathrm{~cm}$ & 701.5 & 42.4 & 673.5 & 74.7 & 891.1 & 44.1 & 684.4 & 56.5 & $\mathrm{~W}<\mathrm{I}$ \\
\hline $10-20 \mathrm{~cm}$ & 850.4 & 34.7 & 947.5 & 46.1 & 1032.4 & 46.9 & 884.1 & 39.4 & $\mathrm{IB}, \mathrm{WF}<\mathrm{IF}$ \\
\hline \multicolumn{10}{|l|}{ Bulk density $\left(\mathrm{g} \cdot \mathrm{cm}^{-3}\right)$} \\
\hline $\mathrm{Oi}-\mathrm{Oe}$ & - & & - & & - & & - & & - \\
\hline $\mathrm{Oa}$ & - & & - & & - & & - & & - \\
\hline $0-10 \mathrm{~cm}$ & 0.87 & 0.03 & 0.88 & 0.07 & 1.00 & 0.07 & 0.84 & 0.06 & NS* \\
\hline $10-20 \mathrm{~cm}$ & 1.04 & 0.04 & 1.23 & 0.07 & 1.20 & 0.07 & 1.09 & 0.07 & $\mathrm{IB}<\mathrm{IF}, \mathrm{WB}$ \\
\hline $20-50 \mathrm{~cm}$ & 1.36 & 0.04 & 1.38 & 0.05 & 1.42 & 0.05 & 1.41 & 0.05 & NS \\
\hline \multicolumn{10}{|c|}{ Carbon concentration $(\%)$} \\
\hline $\mathrm{Oi}-\mathrm{Oe}$ & 45.2 & 0.4 & 41.6 & 1.2 & 41.4 & 1.4 & 38.6 & 1.6 & $\mathrm{~W}<\mathrm{I} ; \mathrm{F}<\mathrm{B} *$ \\
\hline $\mathrm{Oa}$ & 26.8 & 1.2 & 24.9 & 1.8 & 25.2 & 2.0 & 24.2 & 1.9 & NS \\
\hline $0-10 \mathrm{~cm}$ & 4.2 & 0.3 & 3.4 & 0.3 & 3.6 & 0.3 & 5.9 & 0.5 & $\mathrm{~B}<\mathrm{F}^{* \dagger}$ \\
\hline $10-20 \mathrm{~cm}$ & 2.2 & 0.1 & 1.7 & 0.2 & 1.6 & 0.2 & 2.5 & 0.2 & IF, WB $<\mathrm{IB}, \mathrm{WF}$ \\
\hline $20-50 \mathrm{~cm}$ & 0.7 & 0.1 & 1.0 & 0.1 & 0.7 & 0.1 & 1.1 & 0.2 & $\mathrm{I}<\mathrm{W}^{*}$ \\
\hline $50-65 \mathrm{~cm}$ & 0.2 & 0.0 & 0.5 & 0.1 & 0.3 & 0.0 & 0.5 & 0.2 & $\mathrm{I}<\mathrm{W}^{*}$ \\
\hline $65-80 \mathrm{~cm}$ & 0.1 & 0.0 & 0.3 & 0.1 & 0.2 & 0.0 & 0.3 & 0.1 & NS* \\
\hline
\end{tabular}

barrens $\mathrm{Oi}-\mathrm{Oe}$ than forest $\mathrm{Oi}-\mathrm{Oe}$ and lower $\mathrm{N}$ concentrations in the Oi-Oe horizons under barrens than under forest may result from a more N-rich organic matter shed from forest vegetation than from barrens vegetation (Figs. 2 and 3). Although we found similar nutrient content in the barrens and forest tree tissue, particularly leaves, the small shrubs in the barrens do have a slightly higher $\mathrm{C} / \mathrm{N}$ ratio and lower $\mathrm{N}$ concentration than small shrubs in the forest (Wibiralske 2002). Ericaceous shrubs are abundant in the Pocono till barrens communities (Latham et al. 1996). Plants in this family produce litter with a high content of lignin, phenolics, and waxes. Litter rich in lignin and phenolics have high $\mathrm{C} / \mathrm{N}$ ratios and consequently decompose slowly persisting for a long time as recalcitrant (slow to decompose) residues also with high $\mathrm{C} / \mathrm{N}$ ratios.

The greater mass of barrens $\mathrm{Oa}$ is consistent with our interpretation of barrens producing and accumulating recalcitrant soil organic matter and storing a larger pool of $\mathrm{N}$ in this horizon, though the availability of mineral $\mathrm{N}$ may be low, because the $\mathrm{N}$ is bound in resistant organic complexes. The larger quantities of exchangeable $\mathrm{Ca}, \mathrm{Mg}$, and $\mathrm{K}$ in the Illinoian barrens Oa horizon are primarily due to its much larger mass. With a proportionately larger amount of humus, the Illinoian barrens Oa should supply more exchange sites and thus provide a larger pool of available mineral nutrients (Table 1).

Barrens soils contain more organic matter in the Oa horizon, where recalcitrant organic residues accumulate and where the barrens vegetation concentrates its root biomass. In contrast, forest soils contain more organic matter in the mineral soil than barrens, where the forest vegetation produces a greater root biomass (Table 1; Fig. 9). The higher $\mathrm{C} / \mathrm{N}$ ratios and lower $\mathrm{N}$ concentrations in barrens soils than in forest soils suggest that these communities have been in place for a long time, or, less likely, that there is a rapid response of soil $\mathrm{C}$ pools to changes in vegetation.

The $\mathrm{pH}$ data show all soils to be very acidic (Fig. 6). We do see statistically significant differences, namely a slightly lower $\mathrm{pH}$ in Wisconsinan till soils, particularly Wisconsinan barrens in the upper mineral soil, though we must interpret these results with caution, because all of our data for Wisconsinan barrens are from a single site. However, the means are within 0.3 of a $\mathrm{pH}$ unit, a difference unlikely to affect nutrient availability. Consistent with their high acidity, all soils have high values for exchangeable Al concentration and content, between one and two orders of magnitude greater than the values for exchangeable $\mathrm{Ca}, \mathrm{Mg}$, and $\mathrm{K}$, reflecting the low base saturation in these soils (Wibiralske 2002).

\section{Vegetation nutrient capital dynamics}

As expected, the main source of the differences in vegetation nutrient capital is the disparity in biomass between the barrens and forest. The Pocono till barrens, with their sparse overstory of small-stature trees and dense understory of small shrubs, have much less aboveground biomass and overall contain smaller quantities of macronutrients than the adjacent forest (Figs. 3, 5, 7, and 8). Similarly, the absence of large shrubs in the Wisconsinan barrens, especially scrub 
Fig. 7. Mean tree and large shrub, small woody and herbaceous plant, and coarse root biomass $\left(\mathrm{kg} \cdot \mathrm{ha}^{-1}\right)$. F, forest; B, barrens; IB, Illinoian barrens; WB, Wisconsinan barrens; IF, Illinoian forest; WF, Wisconsinan forest; *, ANOVA on ranks. Error bars are \pm 1 SE.

\section{Biomass}

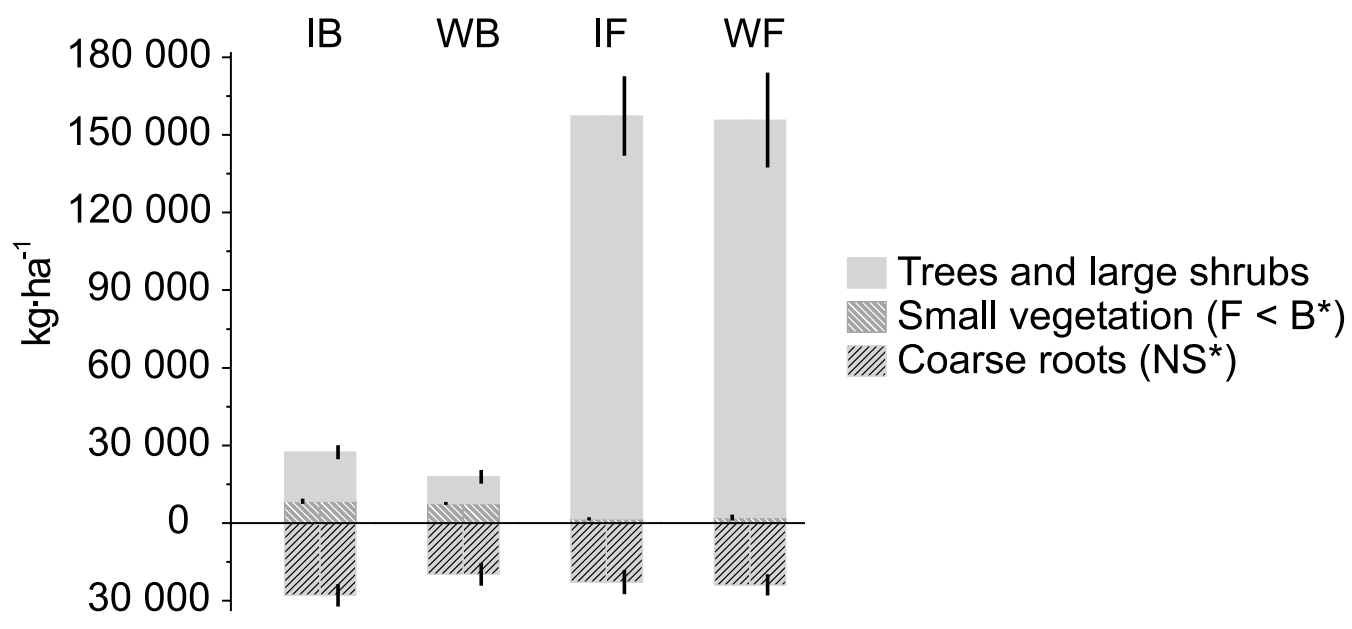

Fig. 8. Mean $\mathrm{Mg}$ content $\left(\mathrm{kg} \cdot \mathrm{ha}^{-1}\right)$ in trees and large shrubs, small woody and herbaceous plants, coarse roots and Oi-Oe horizons and mean exchangeable $\mathrm{Mg}$ content $\left(\mathrm{kg} \cdot \mathrm{ha}^{-1}\right)$ in the Oa horizon and mineral soil to a depth of $50 \mathrm{~cm}$. F, forest; B, barrens; I, Illinoian till; W, Wisconsinan till; IB, Illinoian barrens; WB, Wisconsinan barrens; IF, Illinoian forest; WF, Wisconsinan forest; NS, not significant; $*$, ANOVA on ranks; ${ }^{\dagger}$, significant interaction effect with no post-hoc analysis. Error bars are \pm 1 SE.

\section{Magnesium}

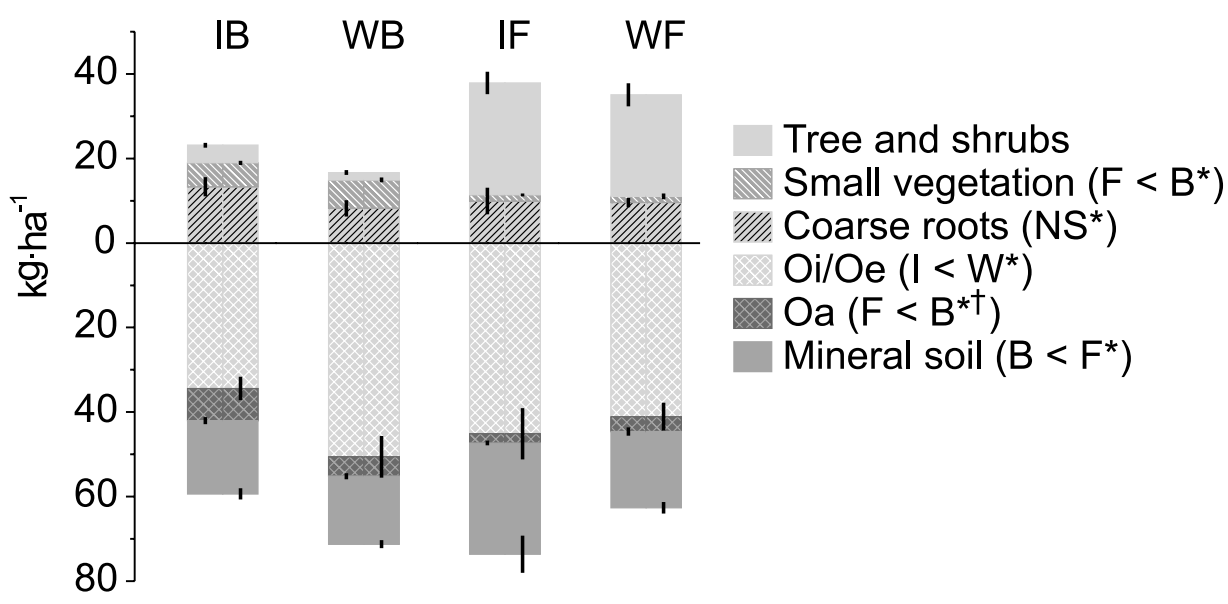

oak which is common in the Illinoian barrens, accounts for the smaller biomass in trees and large shrubs in Wisconsinan barrens than Illinoian barrens.

The two notable exceptions to nutrient content mirroring biomass - (1) the proportionately lower foliar Mg content in Illinoian barrens than Wisconsinan barrens, and (2) the proportionately higher $\mathrm{P}$ content in barrens coarse roots, particularly Illinoian barrens - appear to be related to the occurrence of scrub oak in Illinoian barrens. Scrub oak has a much lower concentration of $\mathrm{Mg}$ in its leaves than the other tree and large-shrub species we sampled, and root samples from plots that contain scrub oak dominate the high end of the Illinoian barrens root $\mathrm{P}$ distributions, with several scrub oak plots having very high values for $\mathrm{P}$ concentration throughout the soil profile (Wibiralske 2002). A study of nutrient con- centrations in the roots of individual species would pinpoint the relative roles of species in the apparent accumulation of $\mathrm{P}$ in roots from scrub oak dominated plant assemblages.

The higher concentration of several macronutrients in the wood of red maple and gray birch trees growing in barrens compared with those growing in the forest also raises questions for further study. These results suggest a greater uptake or sequestering of these nutrients when growing in the barrens. Yet, the analysis of soil nutrients does not show a greater nutrient availability in barrens soils than forest soils. And, consistent with these soil nutrient data, foliar nutrient concentrations, which reflect soil fertility (Linder 1995), show no significant effects associated with parent material or community type (Table 2). An investigation of nutrient mineralization rates and relative environmental stresses between 
Table 2. Elemental concentration $\left(\mu \mathrm{g} \cdot \mathrm{g}^{-1}\right.$ or \%) of leaf and stem tissue of Acer rubrum, Amelanchier arborea, Amelanchier laevis (both species analyzed together), and Betula populifolia growing in barrens and forest on Illinoian and Wisconsin glacial till deposits on the Pocono Plateau in Monroe and Carbon counties in northeastern Pennsylvania.

\begin{tabular}{|c|c|c|c|c|c|c|c|c|c|c|c|c|c|}
\hline \multirow[b]{2}{*}{ Tissue } & \multicolumn{3}{|c|}{ Illinoian barrens } & \multicolumn{3}{|c|}{ Wisconsinan barrens } & \multicolumn{3}{|c|}{ Illinoian forest } & \multicolumn{3}{|c|}{ Wisconsinan forest } & \multirow[b]{2}{*}{ ANOVA results } \\
\hline & Mean & SE & $n$ & Mean & SE & $n$ & Mean & $\mathrm{SE}$ & $n$ & Mean & SE & $n$ & \\
\hline \multicolumn{14}{|l|}{ Acer rubrum } \\
\hline Stem Ca $\left(\mu \mathrm{g} \cdot \mathrm{g}^{-1}\right)$ & 1976.4 & 504.3 & 7 & 2624.6 & 444.3 & 3 & 1613.2 & 284.5 & 10 & 1394.8 & 227.2 & 8 & NS \\
\hline Leaf $\mathrm{Mg}\left(\mu \mathrm{g} \cdot \mathrm{g}^{-1}\right)$ & 818.4 & 111.2 & 7 & 1041.7 & 140.9 & 3 & 827.6 & 67.4 & 9 & 1033.9 & 127.6 & 6 & NS \\
\hline Stem Mg $\left(\mu \mathrm{g} \cdot \mathrm{g}^{-1}\right)$ & 185.9 & 36.7 & 7 & 258.7 & 35.9 & 3 & 172.1 & 30.2 & 10 & 134.7 & 17.4 & 8 & NS* \\
\hline Leaf $P\left(\mu g \cdot g^{-1}\right)$ & 1131.2 & 36.0 & 7 & 1188.6 & 99.6 & 3 & 1145.1 & 89.8 & 9 & 1398.8 & 247.2 & 6 & NS \\
\hline Stem $\mathrm{P}\left(\mu \mathrm{g} \cdot \mathrm{g}^{-1}\right)$ & 102.9 & 5.8 & 7 & 108.7 & 14.0 & 3 & 79.1 & 5.3 & 10 & 76.3 & 4.0 & 8 & $\mathrm{~F}<\mathrm{B}$ \\
\hline Leaf N $(\%)$ & 1.78 & 0.07 & 7 & 1.73 & 0.10 & 3 & 1.84 & 0.07 & 9 & 1.78 & 0.11 & 6 & NS \\
\hline Stem N (\%) & 0.12 & 0.01 & 7 & 0.17 & 0.03 & 3 & 0.11 & 0.00 & 10 & 0.12 & 0.01 & 8 & $\mathrm{~F}<\mathrm{B}^{*}$ \\
\hline Leaf $\mathrm{C} / \mathrm{N}$ ratio & 27.5 & 1.0 & 7 & 28.6 & 1.7 & 3 & 26.4 & 1.2 & 9 & 27.7 & 1.9 & 6 & NS \\
\hline Stem Ca $\left(\mu \mathrm{g} \cdot \mathrm{g}^{-1}\right)$ & 3038.4 & 623.1 & 4 & 2701.3 & 516.2 & 3 & 2917.5 & 655.2 & 4 & 2564.3 & 385.9 & 4 & NS \\
\hline Leaf $\mathrm{Mg}\left(\mu \mathrm{g} \cdot \mathrm{g}^{-1}\right)$ & 1590.4 & 140.2 & 4 & 1880.4 & 100.0 & 2 & 1696.9 & 180.8 & 4 & 2249.2 & 394.0 & 3 & NS* \\
\hline Stem Mg $\left(\mu \mathrm{g} \cdot \mathrm{g}^{-1}\right)$ & 243.5 & 18.0 & 4 & 205.6 & 17.3 & 3 & 272.2 & 57.5 & 4 & 206.5 & 16.5 & 4 & NS \\
\hline Leaf $K\left(\mu g \cdot g^{-1}\right)$ & 9125.6 & 1044.3 & 4 & 7696.6 & 1034.1 & 2 & 9503.2 & 679.2 & 4 & 8871.2 & 1236.0 & 3 & NS \\
\hline Stem $K\left(\mu \mathrm{g} \cdot \mathrm{g}^{-1}\right)$ & 599.4 & 81.7 & 4 & 632.0 & 81.7 & 3 & 481.2 & 127.4 & 4 & 441.9 & 43.6 & 4 & NS \\
\hline Leaf $\mathrm{P}\left(\mu \mathrm{g} \cdot \mathrm{g}^{-1}\right)$ & 1056.6 & 25.1 & 4 & 1191.2 & 45.2 & 2 & 1050.7 & 48.8 & 4 & 1380.7 & 90.5 & 3 & $\mathrm{I}<\mathrm{W}$ \\
\hline Stem $P\left(\mu g \cdot g^{-1}\right)$ & 92.6 & 10.6 & 4 & 77.2 & 7.0 & 3 & 91.4 & 25.2 & 4 & 76.6 & 7.7 & 4 & NS \\
\hline Leaf N (\%) & 1.65 & 0.09 & 4 & 1.69 & 0.04 & 2 & 1.8 & 0.19 & 4 & 1.82 & 0.05 & 3 & NS \\
\hline Stem N (\%) & 0.14 & 0.01 & 4 & 0.15 & 0.01 & 3 & 0.14 & 0.02 & 4 & 0.13 & 0.01 & 4 & NS \\
\hline Leaf $\mathrm{C} / \mathrm{N}$ ratio & 30.2 & 1.5 & 4 & 29.4 & 1.0 & 2 & 27.6 & 2.7 & 4 & 26.5 & 0.9 & 3 & NS \\
\hline Stem $\mathrm{C} / \mathrm{N}$ ratio & 347.1 & 28.2 & 4 & 315.8 & 21.9 & 3 & 359.4 & 42.9 & 4 & 376.4 & 31.2 & 4 & NS \\
\hline Leaf $\mathrm{P}\left(\mu \mathrm{g} \cdot \mathrm{g}^{-1}\right)$ & 1197.6 & 33.8 & 5 & 1237.1 & 136.7 & 3 & - & - & - & 1359.2 & 102.9 & 3 & NS \\
\hline Stem $\mathrm{P}\left(\mu \mathrm{g} \cdot \mathrm{g}^{-1}\right)$ & 123.6 & 8.7 & 6 & 87.6 & 3.1 & 4 & 93.7 & 10.8 & 4 & 78.4 & 4.3 & 6 & $\mathrm{~W}<\mathrm{I} ; \mathrm{F}<\mathrm{B}$ \\
\hline Leaf N $(\%)$ & 2.07 & 0.06 & 5 & 2.15 & 0.16 & 3 & - & - & - & 2.22 & 0.03 & 3 & NS \\
\hline Stem N (\%) & 0.19 & 0.02 & 6 & 0.19 & 0.02 & 4 & 0.16 & 0.01 & 4 & 0.17 & 0.01 & 6 & NS \\
\hline Leaf $\mathrm{C} / \mathrm{N}$ ratio & 24.1 & 0.9 & 5 & 23.2 & 1.5 & 3 & - & - & - & 22.0 & 0.4 & 3 & NS \\
\hline Stem $\mathrm{C} / \mathrm{N}$ ratio & 264.4 & 27.2 & 6 & 261.1 & 24.9 & 4 & 316.9 & 24.9 & 4 & 300.1 & 17.8 & 6 & NS \\
\hline
\end{tabular}

Note: NS, not significant; F, forest; B, barrens; I, Illinoian till; W, Wisconsinan till.

*ANOVA on ranks.

${ }^{\dagger}$ Significant interaction effect with no post-hoc analysis.

barrens and forest would further our understanding of why these tree species sequester a greater quantity of nutrients in their wood when growing in the barrens than in the forest.

\section{Barrens and forest dynamics and the alternative community states hypothesis}

The dramatic conversion of barrens to forest on the Pocono Plateau during much of the last century (Thompson 1995; Latham et al. 1996) strongly indicates that the soils forming in Wisconsinan and Illinoian till on the Pocono Pla- teau support both barrens and forest vegetation, and that a set of dynamics is in place that favors forest vegetation over barrens. Latham (2003) proposes a mixed model, including environmental and biotic factors, to explain past and present trends in vegetation dynamics on the Pocono Plateau. His analysis of the associations between fire history and barrens persistence gives rise to an alternative community states hypothesis, which asserts that barrens or forest may occupy a site as a persistent plant community maintained by positive feedbacks, with a pulse event allowing a switch from one 
Fig. 9. Mean $\mathrm{P}$ content $\left(\mathrm{kg} \cdot \mathrm{ha}^{-1}\right)$ in trees and large shrubs, small woody and herbaceous plants, and coarse roots. F, forest; B, barrens; IB, Illinoian barrens; WB, Wisconsinan barrens; IF, Illinoian forest; WF, Wisconsinan forest; NS, not significant;*, ANOVA on ranks; $\dagger$, significant interaction effect with no post-hoc analysis. Error bars are $\pm 1 \mathrm{SE}$.

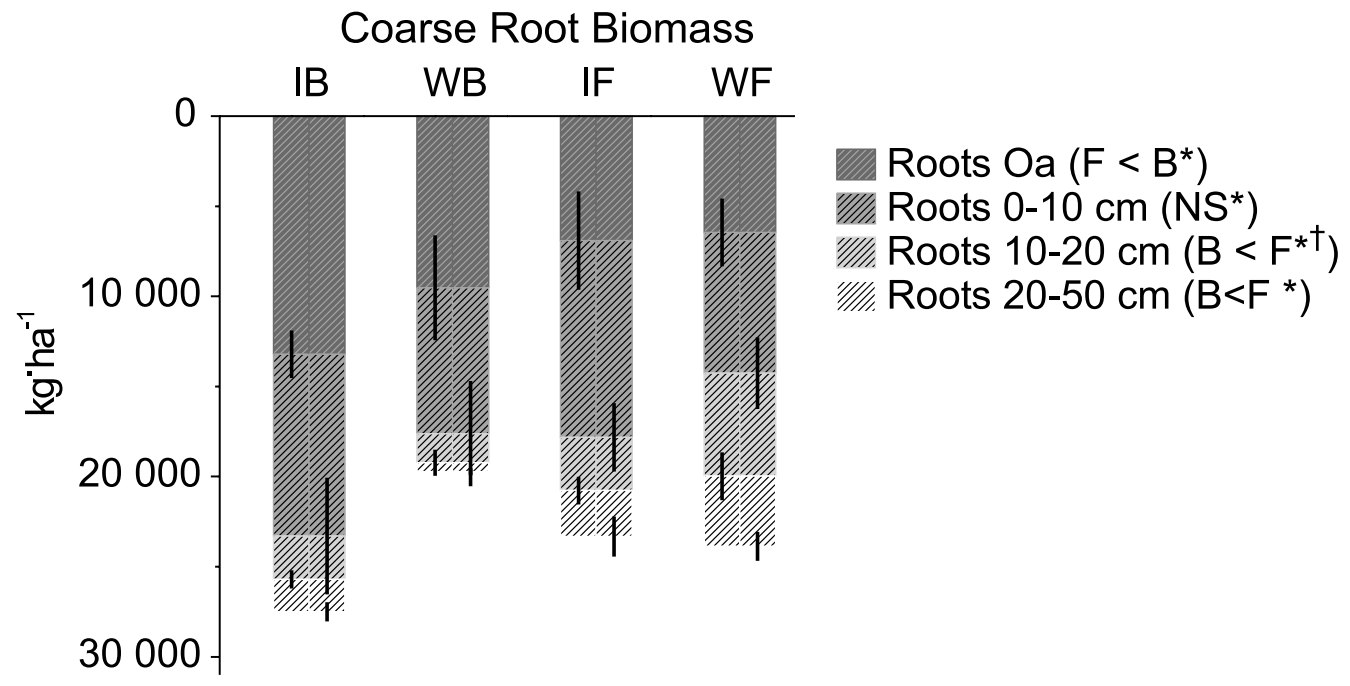

relatively stable state to another (Wilson and Agnew 1992; Petraitis and Latham 1999).

According to this hypothesis (Latham et al. 1996; Petraitis and Latham 1999; Latham 2003), the dominance in the barrens by plants that are both very fire tolerant and pyrogenic (Bond and Midgley 1995; Zedler 1995) increases flammability, promoting the spread of ignitions into large-scale wildfires that kill invading forest species and enable barrens species to dominate. Simultaneously, the barrens vegetation immobilizes nitrogen in its recalcitrant litter, decreasing available nitrogen. With access to organic nitrogen through mycorrhizal fungal symbionts (Read 1983; Dighton and Coleman 1992; Leake 1992) as well as high efficiency in nitrogen use, the dominant barrens species outcompete forest plants for nitrogen and are thus able to resist invasion and persist for longer periods between fires. Inhibition of forest tree establishment makes long-term shrubland persistence more likely in the face of prolonged wet periods, haphazard ignitions, and other sources of variability in the frequency of fire.

Forest vegetation on the other hand, particularly the northern hardwoods type in eastern North America, is not very flammable except in severe drought conditions (Lorimer 2001); therefore, forest fires are few and small. In addition, forest litter readily decomposes and releases nitrogen in mineral form, which increases nitrogen availability in forest soil. Both the absence of fire and the availability of nitrogen allow forest trees to persist and shade barrens plants, outcompeting them for light.

A severe fire in the forest during extreme drought, followed by sufficient recruitment of barrens species, is a pulse event that can switch forest to barrens. Fire suppression, on the other hand, might be thought of as a slow-acting switch converting barrens to forest by allowing gradual invasion by one forest species (red maple) into the barrens (see Fig. 5 in Petraitis and Latham 1999, p. 437). The extensive conversion of barrens to red maple dominated forest from 1938 to 1992 suggests that the institution of fire suppression on the southern Pocono Plateau starting in the late 1950s has dis- rupted the role of fire in maintaining the barrens and permitted the feedbacks that maintain forests to predominate.

Although the barrens have a much smaller biomass overall, the larger biomass in small woody vegetation contributes to the flammability of this plant community. Not only are these plants flammable when green (Latham et al. 1996), but at least $13 \%$ of the standing small-vegetation biomass in the barrens is dead and thus readily combustible, further contributing to the fire-driven positive feedbacks hypothesized to maintain the barrens. An important attribute of some fire-tolerant plants is the ability to sprout new shoots rapidly to replace those killed by fire. Plants with the ability to sprout typically have a high root:shoot ratio. Although we did not measure root biomass and small-shrub aboveground biomass by species, the high belowground : aboveground biomass ratio for the Pocono barrens strongly suggests high root:shoot ratios for the barrens plant species, many of which are sprouters (Fig. 7).

The biomass $\mathrm{N}$-concentration data are also consistent with the nitrogen dynamics predicted by the alternative community states hypothesis. Nitrogen concentration in aboveground small woody vegetation is lower in the barrens than in the forest, suggesting that barrens small shrubs have a higher nitrogen use efficiency than forest small shrubs. However, $\mathrm{N}$ concentrations in aboveground tree and large-shrub biomass and root biomass are similar in barrens and forest (Wibiralske 2002). Most of the forest biomass is in trees and large shrubs, with relatively high foliar $\mathrm{N}$ concentrations, whereas a sizable portion of the barrens biomass is in small shrubs with low $\mathrm{N}$ concentrations. Assuming that the dominant species in each community exert a strong influence on nitrogen cycling, the results of this study support the alternative community states hypothesis. However, more information is necessary to assess the extent to which the $\mathrm{N}$ feedbacks predicted by this hypothesis may maintain a stable barrens or forest ecosystem. An analysis of $\mathrm{N}$ fluxes between ecosystem components, particularly litterfall- $\mathrm{N}$ and $\mathrm{N}$ mineralization rates, and an assessment of the extent to 
which mycorrhizal fungal symbionts have direct access to organic $\mathrm{N}$ would contribute valuable information to our understanding of $\mathrm{N}$ cycling in the barrens and forest.

The frost pocket phenomenon (Hough 1945) may be another plant-driven positive feedback that favors barrens (Latham et al. 1996; Motzkin et al. 2002). Frost pockets typically occur in small-stature plant communities on windless, cool, clear nights when heat stored in the ground during the day radiates back into space unimpeded by the insulation of clouds or tree-canopy cover, trapping cooler air in topographic depressions. Frost pockets can also occur in topographically level shrublands (Motzkin et al. 2002). In forested regions frost pockets may be initiated by a disturbance that removes forest vegetation, such as logging or severe fire (Hough 1945). Frequent and severe late spring frost damage, which is common on the Pocono barrens and vicinity (Dixon Miller, Pennsylvania Bureau of Forestry, unpublished data; personal observation by the authors), may favor frost-tolerant barrens shrubs and retard or prohibit invasion by larger-stature trees and shrubs, whose canopy could provide sufficient insulation to eliminate the frost pocket.

\section{Conclusion}

With the lack of evidence for a lower nutrient content in the Illinoian till soils than in Wisconsinan till soils and with an understanding of the fire and plant community type dynamics predicted by the alternative community states hypothesis, the high correlation between barrens and Illinoian till appears to be a coincidence of topography (Latham et al. 1996). The flat terrain of the southern Pocono Plateau slows erosion allowing the Illinoian till to persist there. Fires that start at the dry, drought-prone escarpment rim easily spread across this flat terrain, blown by the prevailing southwest winds, until they reach the natural firebreak of Tunkhannock Creek and its broad corridor of streamside wetlands. Only where the wetland fringe narrows, permitting a fire to jump the creek, do we find a few small patches of barrens north of Tunkhannock Creek. At one of these places, the Wisconsinan barrens site, the Wisconsinan terminal moraine flanks the north bank of the creek. At this site and in the Illinoian till deposits south of the creek, wildfires and barrens have been a prominent part of the landscape's history.

Contrary to our expectation, a 10-fold difference in the age of the underlying glacial till does not exert a substantial influence on the plant nutrient capital in the barrens and forest. The differences we found in soil properties are consistent with those predicted by the alternative community states hypothesis, namely, a higher $\mathrm{C} / \mathrm{N}$ ratio in both the litter and soil organic matter under barrens than under forest and a larger Oa horizon in Illinoian barrens soil, presumably the result of an accumulation of recalcitrant, N-sequestering, decomposition residues in this horizon. By offering no evidence for inherited soil nutrients controlling or even strongly influencing the presence or persistence of barrens or forest, our results reinforce an explanation rooted in factors operating primarily outside the soil environment. Differences in biomass associated with plant community type, on the other hand, clearly give rise to the patterns of differences in vegetation nutrient capital between barrens and forest. These findings lend support to the idea that instead of soil nutri- ents, vegetation characteristics — particularly those related to feedback relationships with fire and perhaps also those influencing nitrogen cycling and frost pockets - play the key role in determining the contrasting dynamics of barrens and forest on the Pocono Plateau.

\section{Acknowledgements}

This research was supported by grants to Arthur Johnson from the Andrew W. Mellon Foundation and to Roger Latham from the Nature Conservancy. We are grateful to David Vann and Marty Dranoff for data analysis and laboratory expertise, to Janet Scannell for computer programming assistance, and to two anonymous reviewers for comments and critique. Thanks also to Dixon Miller, Pennsylvania Bureau of Forestry, for kindly supplying data and other information; to Ellen Lott for logistical support; and to Bob Bartel, Jeff Castelli, Charlie Cho, Chris Cianfrani, Stephanie Feingold, Etan Gumerman, Michele Hannon, Lynn Heilman, Rich McHorney, Mathew Mellon, Kathleen Meade, Sally Pick, Sarah Riley, Dana Royer, Tom Stich, Suzanne Thomas, John Thompson, Bridget Ward, Pam White, and Martha Young for field and lab sample processing.

\section{References}

Anderson, R.C., Fralish, J.S., and Baskin, J.M. (Editors.) 1999. Savannas, barrens and rock outcrop plant communities of North America. Cambridge University Press, New York.

Berg, T.M., Sevon, W.D., and Bucek, M.F. 1977. Geology and mineral resources of the Pocono Pines and Mount Pocono quadrangles, Monroe County, Pennsylvania. Atlas 204cd. Pennsylvania Department of Environmental Research, Topographical and Geological Survey, Harrisburg, Pa.

Berg, T.M., Barnes, J.H., Sevon, W.D., Skema, V.W., Wilshusen, J.P., and Yannacci, D.S. 1989. Physiographic provinces of Pennsylvania. Map 13. Pennsylvania Department of Environmental Research, Topographical and Geological Survey, Harrisburg, Pa.

Bond, W.J., and Midgley, J.J. 1995. Kill thy neighbor: an individualistic argument for the evolution of flammability. Oikos, 73: 79-85.

Braun, E.L. 1950. Deciduous forests of eastern North America. The Blakiston Co., Philadelphia, Pa.

Burnham, C.F., Ferree, M.J., and Cunningham, F.E. 1947. The scrub oak forests of the anthracite region. USDA For. Serv., Philadelphia.

Crowl, G.H. 1980. Woodfordian age of the Wisconsin glacial border in northeastern Pennsylvania. Geology, 8: 51-55.

Crowl, G.H., and Sevon, W.D. 1980. Glacial Border deposits of late Wisconsinan age in northeastern Pennsylvania. Gen. Geol. Rep. 71. Pennsylvania Department of Environmental Research, Topographical and Geological Survey, Harrisburg, Pa.

Davis, A.G., Edinger, G.J., Andersen, S.B., Wilkinson, A.M., and Belfonti, J.R. 1991. Natural areas inventory of Monroe County, Pennsylvania. Pa. Sci. Off., The Nature Conservancy, Middletown, Pa., for Monroe County Planning Comm., Stroudsburg, $\mathrm{Pa}$.

Dighton, J., and Coleman, D.C. 1992. Phosphorus relations of roots and mycorrhizas of Rhododendron maximum L. in the southern Appalachians, North Carolina. Mycorrhiza, 1: $175-184$. 
Eberhardt, R.W., and Latham, R.E. 2000. Relationships among vegetation, surficial geology and soil water content at the Pocono mesic till barrens. J. Torrey Bot. Soc. 127: 115-124.

Fisher, G., Mattern, R., McCombs, R., Norgren, J., and Rebert, A. 1962. Soil survey of Carbon County, Pennsylvania. USDA Soil Conserv. Serv., Washington, D.C.

Hamburg, S.P. 1984. Effects of forest growth on soil nitrogen and organic matter pools following release from subsistence agriculture. In Forest soils and treatment impacts. Edited by E.L. Stone. University of Tennessee, Knoxville, Tenn. pp. 145-158.

Homoya, M.A. 1994. Barrens as an ecological term: an overview of usage in the scientific literature. In Living in the edge: proceedings of the North American Conference on savannas and barrens, 15-16 October 1994, Illinois State University, Normal, Ill. Edited by J.S. Fralish, R.C. Anderson, J.E. Ebinger, and R. Szafoni. Illinois State University, Normal, Ill. pp. 295-303.

Hough, A.F. 1945. Frost pocket and other microclimates in forests of the northern Allegheny Plateau. Ecology, 26: 235-250.

Latham, R.E. 2003. Shrubland longevity and rare plant species in the northeastern USA. For. Ecol. Manage. 185: 21-39.

Latham, R.E., Thompson, J.E., Riley, S.A., and Wibiralske, A.W. 1996. The Pocono till barrens: shrub savanna persisting on soils favoring forest. Bull. Torrey Bot. Club, 123: 330-349.

Leake, J.R. 1992. The role of ericoid mycorrhizas in nitrogen nutrition and ecology of heathland ecosystems. In Mycorrhizas in Ecosystems. Edited by D.J. Read, D.H. Lewis, A.H. Fitter, and I.J. Alexander. CAB International, Wallingford, UK. pp 227-236.

Linder, S. 1995. Foliar analysis for detecting and correcting nutrient imbalances in Norway spruce. Ecol. Bull. 44: 178-190.

Lipscomb, G.H. 1981. Soil survey of Monroe County, Pennsylvania. U.S.D.A. Soil Conserv. Serv., Washington, D.C.

Lorimer, C.G. 2001. Historical and ecological roles of disturbance in eastern North American forests: 9,000 years of change. Wildl. Soc. Bull. 29: 425-439.

McQuilkin, W.E. 1961. Scrub oak conversion. In Forest and water research project. Delaware-Lehigh Exp. For. Rep. No. 4. Pa. Dept. of For., and Waters, Harrisburg, Pa. pp. 1-16.

Motzkin, G., Ciccarello, S.C., and Foster D.R. 2002. Frost pockets on a level sand plain: Does variation in microclimate help maintain persistent vegetation patterns? J. Torrey Bot. Soc. 129: 154-163

Olsvig, L.S. 1980. A comparative study of Northeastern pine barrens vegetation. Ph.D. dissertation, Cornell University, Ithaca, N.Y.

Owenby, J.R., and Ezell, D.S. 1992. Monthly station normals of temperature, precipitation, and heating and cooling degree days 1961-90: Pennsylvania. Climatography of the US. No. 81. NOAA, National Climatic Data Center, Asheville, N.C.
Petraitis, P.S., and Latham, R.E. 1999. The importance of scale in testing the origins of alternative community states in ecosystems. Ecology, 80: 429-442.

Read, D.J. 1983. The biology of mycorrhizae in the Ericales. Can. J. Bot. 61: 958-1004.

Reed, P.B., Jr. 1988. National list of plant species that occur in wetlands: Northeast (Region 1). Bio. Rep. 88 (26.1). U.S. Dept. of the Interior, Fish and Wildlife Service, Washington, D.C.

Robarge, W.P., and Fernandez, I. 1987. Quality assurance methods for laboratory analytical techniques. For. Resp. Prog., US EPA and US For. Serv., Corvallis, Ore.

Sevon, W.D. 1975a. Geology and mineral resources of the Christmans and Pohopoco Mountain quadrangles, Carbon and Monroe Counties, Pennsylvania. Atlas 195ab. Pennsylvania Department of Environmental Research, Topographical and Geological Survey, Harrisburg, Pa.

Sevon, W.D. 1975b. Geology and mineral resources of the Hickory Run and Blakeslee quadrangles, Carbon and Monroe Counties, Pennsylvania. Atlas 194cd. Pennsylvania Department of Environmental Research, Topographical and Geological Survey, Harrisburg, Pa.

Soil Survey Staff. [online]. Official Soil Series Descriptions. National Resources Conservation Service, USDA. Available from http://soils.usda.gov/technical/classification/osd/index.html/ [Accessed 29 August 2004].

Sokal, R.R., and Rohlf, F.J. 1995. Biometry: the principles and practice of statistics in biological research. W.H. Freeman and Company, San Francisco, Calif.

Ter-Mikaelian, M.T., and Korzukhin, M.D. 1997. Biomass equations for sixty-five North American tree species. For. Ecol. Manage. 97: 1-24.

Thompson, J.E. 1995. Interrelationships among vegetation dynamics, fire, surficial geology, and topography of the southern Pocono Plateau, Monroe County, Pennsylvania. M.S. thesis, Geology Department, University of Pennsylvania, Philadelphia, Pa.

Tritton, L.M., and Hornbeck, J.W. 1982. Biomass equations for major tree species of the Northeast. U.S. Dep. Agric. For. Serv. Gen. Tech. Rep. NE-69: 46.

Whittaker, R.H., and Woodwell, G.M. 1968. Dimension and production relations of trees and shrubs in the Brookhaven Forest, New York. J. Ecol. 56: 1-25.

Wibiralske, A. 2002. A comparative study of soil and vegetation nutrient capital between the Pocono till barrens and adjacent hardwood forest and between Illinoian and Wisconsinan till. Ph.D. Dissertation, University of Pennsylvania, Philadelphia, Pa.

Wilson, J.B., and Agnew, A.D.Q. 1992. Positive-feedback switches in plant communities. Adv. Ecol. Res. 23: 263-336.

Zedler, P.H. 1995. Are some plants born to burn? Trends Ecol. Evol. 10: 393-395. 